\title{
МЕТОДИЧЕСКИЕ РЕКОМЕНДАЦИИ ПО ОПТИМИЗАЦИИ НАЛОГООБЛОЖЕНИЯ ГОРИЗОНТАЛЬНО - ИНТЕГРИРОВАННЫХ ОБЪЕДИНЕНИЙ АПК
}

Аннотация: сущность налогового планирования заключается в признании за каждым налогоплательщиком права использовать все допустимые законами средства, приемы и способы для максимального сокращения своих налоговых обязательств. Так, в основе данного процесса лежит максимально полное и правильное использование всех установленных законом льгот и преимуществ, а также оченка позищии налоговых органов и учет основных направлений налоговой, бюджетной и инвестиционной политики государства. Основными иелями налогового планирования является: оптимизация налоговых платежей, минимизациия налоговых потерь по конкретному налогу или по их совокупности, увеличение объема оборотных средств предприятия, повышение эффективности работы организации.Особый интерес вызывает оптимизация налогообложения в сфере вертикально-интегрированных объединений АПК. Следует отметить, что система налогообложения сельскохозяйственных предприятий в России, в том числе и интегрированных, имеет свои особенности, что позволяет выделить этапы налоговой оптимизации исследуемых структур. Нам представляется, что оптимизачию налогообложения в сельскохозяйственных предприятиях, в том числе и интегрированных, следует основывать на:

- четком соблюдении принципов налоговой оптимизацчии;

- выборе оптимальной организационно-правовой формы хозяйствова-ния предприятий;

- учете влияния субъективных и объективных факторов, а также отрас-левых особенностей при выборе той или иной системы налогообложения;

- выборе методов учета доходов и расходов;

- использовании различных критериев оценки с иелю обоснованного выбора оптимальной налоговой схемы

Ключевые слова: налоговое планирование, оптимизация налоговых платежей, интегрированные формирования, сельхозтоваропроизводители, особенности сельскохозяйственных предприятий, этапь налоговой оптимизации, методы учета, ЕСХН, общий режим налогообложения, налоговая нагрузка.

Review: the purpose of tax planning is to declare a taxpayer's right to use all legal means and methods to reduce their tax liabilities as much as possible. Thus, at the heart of this process there is a full and rightful usage of all legally permitted benefits and advantages as well as assessment of tax authorities' positions and consideration of taxation, budgetary and investment policies. The main goals of tax planning include: tax optimization, minimization of lost taxes based on a particular tax or combination of taxes, increase in corporate asset circulation and better performance of an enterprise. Special 
attention is paid at tax optimization in the sphere of vertically integrated units of agro-industrial sector. It should be noted that the system of taxation of agricultural enterprises in Russia including integrated enterprises has a number of peculiarities. This allows to describe particular stages in optimization of the sector under review. The author believes that tax optimization at agricultural enterprises including integrated enterprises should be based on the following: strict observance of the principles of tax optimization; selection of the best legal form of economic management; consideration of influence of subjective and objective factors as well as industry characteristics when choosing this or that taxation system; selection of income and expense accounting methods; usage of different evaluation criteria in order to find the best taxation scheme.

Keywords: tax planning, tax optimization, integrated units, agricultural producers, peculiarities of agricultural enterprises, stages in tax optimization, accounting methods, Single Agricultural Tax, standard taxation scheme, tax burden.

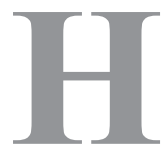
алоговое планирование является легальным путем уменьшения налоговых обязательств путем корректировки финансово-хозяйственной деятельности, структуры финансовых и товарных потоков организации при строгом соблюдении налогового законодательства и с учетом сложившейся арбитражной практики.

Следует отметить, что сущность налогового планирования заключается в признании за каждым налогоплательщиком права использовать все допустимые законами средства, приемы и способы для максимального сокращения своих налоговых обязательств.

Так, в основе данного процесса лежит максимально полное и правильное использование всех установленных законом льгот и преимуществ, а также оценка позиции налоговых органов и учет основных направлений налоговой, бюджетной и инвестиционной политики государства.

Основными целями налогового планирования является: оптимизация налоговых платежей, минимизация налоговых потерь по конкретному налогу или по их совокупности, увеличение объема оборотных средств предприятия, повышение эффективности работы организации.

Нам представляется, что описываемый процесс планирования подразумевает оп- тимизацию налогообложения в целом, разработку ситуационных схем оптимизации налоговых платежей, организацию системы налогообложения для своевременного анализа налоговых последствий различных управленческих решений.

Возможность осуществления налоговой оптимизации обусловлена, прежде всего, следующим.

Во-первых, действующее гражданское законодательство допускает осуществление хозяйственной деятельности в различных правовых формах по выбору субъекта предпринимательской деятельности (например, путем создания юридического лица или путем заключения договора простого товарищества), а различные правовые формы предполагают различный порядок налогообложения.

Во-вторых, часто налогоплательщик вправе выбирать непосредственно режим налогообложения для своего предприятия (например, ЕСХН или общая система налогообложения).

В-третьих, законодательство о налогах и сборах предоставляет налогоплательщику возможность выбирать различные методы учета хозяйственных операций для целей налогообложения по своему усмотрению (например, выбор метода списания стоимо- 


\section{Налоги и налогообложение - №10(112)• 2013}

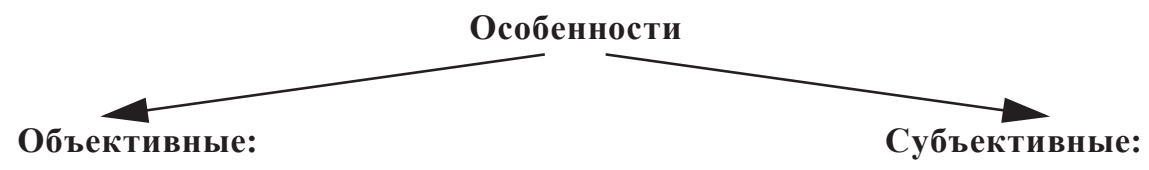

- $\quad$ прямая зависимость результатов с.х производства от природно-климатических условий

- $\quad$ сезонность основных отраслей производства
- состав и доходность отраслей производства

- обеспеченность рабочей силой

- уровень изношенности средств производства

- $\quad$ месторасположение с.х. предприятия

- $\quad$ размеры и структура с.х.угодий и др.

Рисунок 1. Особенности сельскохозяйственных предприятий

сти материалов на расходы в целях налогообложения), а также принимать по своему усмотрению иные решения, непосредственно влияющие на налогообложение (например, использовать или не использовать право на освобождение от уплаты налога на добавленную стоимость).

На наш взгляд особый интерес вызывает оптимизация налогообложения в сфере вертикально-интегрированных объединений АПК. Так, система налогообложения сельскохозяйственных предприятий в России, в том числе и интегрированных, имеет свои особенности. На основе проведенных аналитических исследований мы выделяем следующее.

Возможность использования сельскохозяйственными товаропроизводителями (как организациями, так и для индивидуальными предпринимателями) нескольких режимов налогообложения: общего режима налогообложения, специального налогового режима в виде единого сельскохозяйственного налога (ECXH), упрощенной системы налогообложения, причем сторонники сельскохозяйственного налога преследуют решение двух основных проблем: снижение налогового бремени и упрощение процедуры взимания налога.

Следует отметить, что существует ряд особенностей сельхозпредприятий, которые непосредственно оказывают влияние на выбор той или иной системы налогообложения.
Их можно разделить на объективные и субъективные. Вместе с тем, такое деление носит условный характер (рис. 1).

К объективным, не зависящим от решений экономического субъекта особенностям целесообразно отнести прямую зависимость результатов сельскохозяйственного производства от природно-климатических условий, сезонность основных отраслей производства.

К субъективным особенностям относятся структура, состав и доходность отраслей производства, обеспеченность рабочей силой (особенно при использовании сезонных работников), уровень изношенности средств производства (и, как следствие, наличие или отсутствие потребности в обновлении сельхозтехники), месторасположение сельскохозяйственного предприятия, размеры и структура сельскохозяйственных угодий и др.

Особое внимание при оптимизации налогообложения, на наш взгляд, следует обратить на такие отраслевые особенности, как доля отрасли в доходе от реализации продукции, финансовые результаты деятельности и ресурсоемкость производства.

Так, например, сочетание основных и дополнительных отраслей является законодательным ограничителем при выборе общего или специального режима налогообложения. При этом финансовые результаты выбранных отраслей оказывают влияние на размер нало- 
DOI: $10.7256 / 1812-8688.2013 .10 .9729$

При цитировании этой статьи сноска на doi обязательна

Прогнозирование и планирование в налогообложении

Таблица 1.

Состав уплачиваемых налогов и сборов для разных режимов налогообложения сельхозтоваропроизводителей

Общий режим налогообложения

Единый сельскохозяйственный налог

Налоги и сборы, уплачиваемые в зависимости от системы налогообложения

\begin{tabular}{|c|c|}
\hline Налог на прибыль организаций & \begin{tabular}{c} 
Единый сельскохозяйственный налог \\
\hline Налог на добавленную стоимость
\end{tabular} \\
$\begin{array}{c}\text { Налог на добавленную стоимость } \\
\text { (только при ввозе товаров на таможенную терри- } \\
\text { торию РФ) }\end{array}$ \\
\hline Налог на имущество организаций & налоги и сборы уплачиваемые независимо от применяемой системы налогообложения \\
\hline \multicolumn{2}{|c|}{ Налог на доходы физических лиц, водный налог, государственная пошлина, } \\
транспортный налог и земельный налог
\end{tabular}

га на прибыль. Отраслевые характеристики движения денежных потоков формируют налоговую платежеспособность хозяйствующего субъекта, что очень важно при резко выраженной сезонности сельскохозяйственного производства. От уровня фондо- и трудоемкости производства при сложившемся сочетании отраслей зависит соответственно размер налога на имущество организаций, налога на доходы физических лиц и единого социального налога. Месторасположение сельскохозяйственного предприятия также является стратегическим фактором налоговой оптимизации. Оно непосредственно формирует величину земельного налога и опосредованно оказывает влияние на налогообложение финансовых результатов ${ }^{1}$.

Оптимизацию налогообложения сельскохозяйственного предприятия возможно также в некоторых случаях осуществлять путем выбора метода признания доходов и расходов: кассовый метод (по мере оплаты) и метод начисления (по мере отгрузки). Например, метод начисления дает возможность планирования финансового результата

\footnotetext{
${ }^{1}$ Пестрякова Т. П. Система налогового планирования сельскохозяйственного предприятия / Т. П. Пестрякова // Экономический анализ: теория и практика.-2007.№ 5.- С. 25-30.
}

с учетом соотношения временного лага между получением оплаты и отгрузкой товара, а также уровня инфляции.

Еще одним элементом оперативного (тактического) налогового планирования является выбор оптимальной для сельскохозяйственного предприятия системы налогообложения (табл. 1).

При этом выбор оптимальной системы налогообложения для сельскохозяйственного предприятия может быть основан на использовании следующих критериев оценки (рис. 2).

Подводя итог вышесказанному, можно сделать вывод, что сельское хозяйство имеет свои отраслевые особенности, а также возможность использования льготного налогообложения, следовательно, в процессе налоговой оптимизации, на наш взгляд, целесообразно выделить ряд этапов, которые должны учитывать интегрированные предприятия АПК (табл. 2)².

Первые три этапа налоговой оптимизации обычно происходят только один раз до регистрации организации, а остальные

\footnotetext{
${ }^{2}$ Пестрякова Т.П. Система налогового планирования сельскохозяйственного предприятия / Т.П. Пестрякова // Экономический анализ: теория и практика.—-2007.№ 5.- C. 25-30.
} 


\section{Налоги и налогообложение - №10(112) 2013}

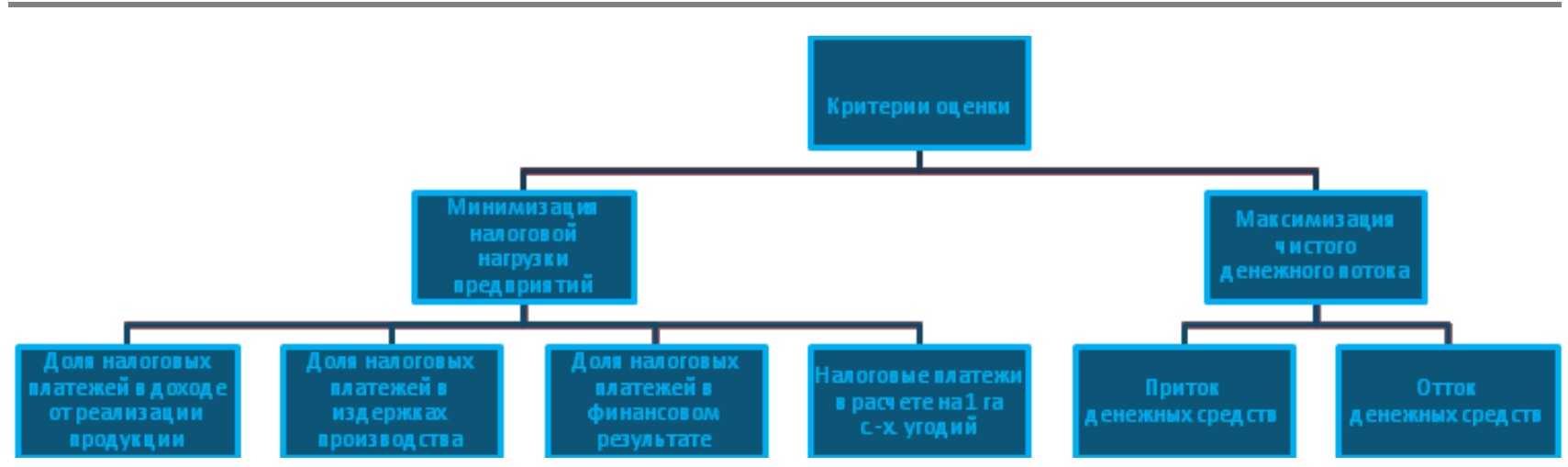

Рисунок 2. Критерии оценки эффективности системы налогообложения для сельскохозяйственного предприятия

Источник: Пестрякова Т.П. Система налогового планирования сельскохозяйственного предприятия / Т. П. Пестрякова // Экономический анализ: теория и практика.-2007.- № 5.

относятся к текущей деятельности и должны осуществляться постоянно в ходе процесса хозяйственной деятельности на всех ее уровнях.

На первом этапе при создании организации, которая будет входить в состав холдинга, необходимо рассмотреть цели и задачи данного предприятия для выбора той или иной системы налогообложения, льготные особенности которой непосредственно будут влиять на уровень налоговой нагрузки как конкретного предприятия, так холдинга в целом.

На втором этапе при выборе месторасположения с налоговой точки зрения организации и ее структурных подразделений, входящих в состав холдинга, следует учитывать особенности местного законодательства, а именно величину земельного налога, который опосредованно оказывает влияние на налогообложение финансовых результатов.

Этап процесса выбора оптимальной с точки зрения налогообложения организационно-правовой формы сельскохозяйственного предприятия состоит из трех стадий:

- выбор формы собственности;

- вид имущественной собственности;

- $\quad$ законодательные ограничения при организации (реорганизации).
На первой стадии осуществляется выбор формы собственности и ее юридической регистрации. При этом важную роль играют финансовые и организационные факторы, а также возможности выбора того или иного режима налогообложения.

На второй стадии организационно-правовые формы сельскохозяйственных предприятий оцениваются с учетом степени их юридической и экономической ответственности. Так, п. 7 ст. 46 НК РФ предусматривает погашение налоговый задолженности за счет имущества налогоплательщика. Законодательство РФ разграничивает имущественную ответственность сельскохозяйственного предприятия как юридического лица от ответственности его учредителей. Таким образом, хозяйственные общества (OOO, OAO, ЗАО), а именно их участники несут имущественную ответственность в пределах своих долей, в остальных организационно-правовых формах (товарищества, кооперативы, частное предпринимательство) на них возложена полная имущественная ответственность, распространяющаяся и на большую часть личного имущества учредителей.

При выборе организационно-правовой формы сельскохозяйственного предприятия 


\section{Таблица 2.}

Этапь налоговой оптимизации для интегрированных формирований АПК

\begin{tabular}{|c|c|}
\hline Этапы & Характеристика \\
\hline Первый & $\begin{array}{c}\text { Момент создания коммерческой организации, когда формулируются цели и задачи } \\
\text { нового образования, анализируются все предоставляемые налоговым законодатель- } \\
\text { ством льготы по каждому из налогов }\end{array}$ \\
\hline Второй & $\begin{array}{r}\text { Выбор наиболее выгодного с налоговой точки зрения места расположения организа- } \\
\text { ции и ее структурных подразделений, входящих в состав холдинга }\end{array}$ \\
\hline Третий & $\begin{array}{r}\text { Выбор одной из существущих организационно-правовых форм юридического лица } \\
\text { или формы предпринимательства без образования юридического лица }\end{array}$ \\
\hline Четвертый & $\begin{array}{r}\text { Анализ всех возможных форм сделок, планируемых в коммерческой деятельности, } \\
\text { с точки зрения минимизации совокупных налоговых платежей }\end{array}$ \\
\hline Пятый & $\begin{array}{r}\text { Решение вопроса о рациональном размещении активов и прибыли предприятия, } \\
\text { имея в виду не только предполагаемую доходность инвестиций, но и налоги, упла- } \\
\text { чиваемые при получении этого дохода }\end{array}$ \\
\hline
\end{tabular}

необходимо также учитывать действующие законодательные ограничения (3 стадия). Так, для АО и ООО установлена возможность создания резервного фонда и эмиссии облигаций и других ценных бумаг, что при прочих равных условиях можно рассматривать как своего рода налоговые льготы, возникающие в результате уменьшения размера налогооблагаемой базы.

Четвертый этап подразумевает проведение полноценного предварительного и текущего анализа актуального налогового законодательства на предмет изменений, связанных с уплачиваемыми организацией налоговыми платежами с точки зрения наиболее широкого использования всех предоставляемых предприятию налоговых льгот с целью минимизации налоговых обязательств.

На пятом этапе происходит принятие решения о размещении активов и прибыли предприятия. При этом во внимание берется не только возможная доходность капиталовложений, но и сумма возникающих налоговых обязательств организации перед бюджетами различных уровней и внебюджетными фондами.

Проведя исследование в области применения различных режимов налогообложения в интегрированных формированиях
АПК, как одного из способов оптимизации налогообложения мы пришли к следующим результатам.

Так, можно полагать, что изменение налогового режима с общего на специальный режим налогообложения наибольшим образом влияет на сальдо от операционной деятельности наименее прибыльных хозяйств и приведет к снижению сальдо от операционной деятельности в 2,3 и 1,5 раза соответственно.

Для более детального анализа полученного результата рассмотрим общий и специальный режимы налогообложения в разрезе налогов, входящих в их состав (табл. 3,4 ).

Наибольший объем налоговых отчислений в государственный бюджет поступит от наиболее крупных и прибыльных хозяйств «Предприятие $3 »(5,7$ млн. руб.), «Предприятие 4» (5,0 млн. руб.) и «Предприятие 2» (9,4 млн. руб.) (табл. 4).

В структуре налоговых платежей при общем режиме налогообложения наибольший удельный вес по всем сельскохозяйственным предприятиям составят НДС (12,0 млн. руб.) и страховые взносы (9,9 млн. руб.). Суммарный объем этих налогов в общей величине налогового бремени составит более $67 \%$. Общая величина налогов при исполь- 
DOI: $10.7256 / 1812-8688.2013 .10 .9729$

При цитировании этой статьи сноска на doi обязательна

\section{Налоги и налогообложение - №10(112)• 2013}

Таблица 3. Объем налоговых платежей при общем режиме налогообложения по сельскохозяйственному производству исследуемого интегрированного объединения, тыс. руб.

\begin{tabular}{|c|c|c|c|}
\hline Налоговые платежи & $\mathbf{2 0 1 0}$ г. & $\mathbf{2 0 1 1}$ г. & $\mathbf{2 0 1 2}$ г. \\
\hline Всего налогов & 36827 & 29047 & 382 \\
\hline Налог на прибыль & 3259 & 3585 & 3198 \\
\hline Налог на имущество организаций & 2472 & 2989 & 4879 \\
\hline Транспортный налог & 4505 & 4730 & 5095 \\
\hline Земельный налог & 4632 & 5095 & 4090 \\
\hline НдС & 12050 & 1747 & 11664 \\
\hline
\end{tabular}

Таблица 4. Объем налоговых платежей при общем режиме налогообложения разрезе хозяйств), тыс. руб.

\begin{tabular}{|c|c|c|c|c|c|c|}
\hline & $\begin{array}{l}\text { налог на } \\
\text { прибыль }\end{array}$ & $\begin{array}{c}\text { налог } \\
\text { на иму- } \\
\text { щество } \\
\text { организа- } \\
\text { ций }\end{array}$ & $\begin{array}{c}\text { транс- } \\
\text { портный } \\
\text { налог }\end{array}$ & $\begin{array}{l}\text { земель- } \\
\text { ный на- } \\
\text { лог }\end{array}$ & НДС & $\begin{array}{c}\text { Страховые } \\
\text { взносы }\end{array}$ \\
\hline Предприятие 1 & 210 & 144 & 12 & 505 & 187 & 1094 \\
\hline Предприятие 2 & 1100 & 112 & 4075 & 578 & 2363 & 1229 \\
\hline Предприятие 3 & 268 & 1012 & 152 & 793 & 1846 & 1698 \\
\hline Предприятие 4 & 316 & 857 & 220 & 716 & 1413 & 1533 \\
\hline Предприятие 5 & 412 & 95 & 32 & 383 & 1132 & 812 \\
\hline Предприятие 6 & 321 & 112 & 3 & 811 & 1804 & 1732 \\
\hline Предприятие 7 & 152 & 26 & 5 & 377 & 734 & 803 \\
\hline Предприятие 8 & 480 & 114 & 6 & 469 & 2571 & 1009 \\
\hline Предприятие 9 & 225 & 98 & 5 & 381 & 1318 & 915 \\
\hline Предприятие 10 & 302 & 111 & 7 & 514 & 1659 & 997 \\
\hline
\end{tabular}

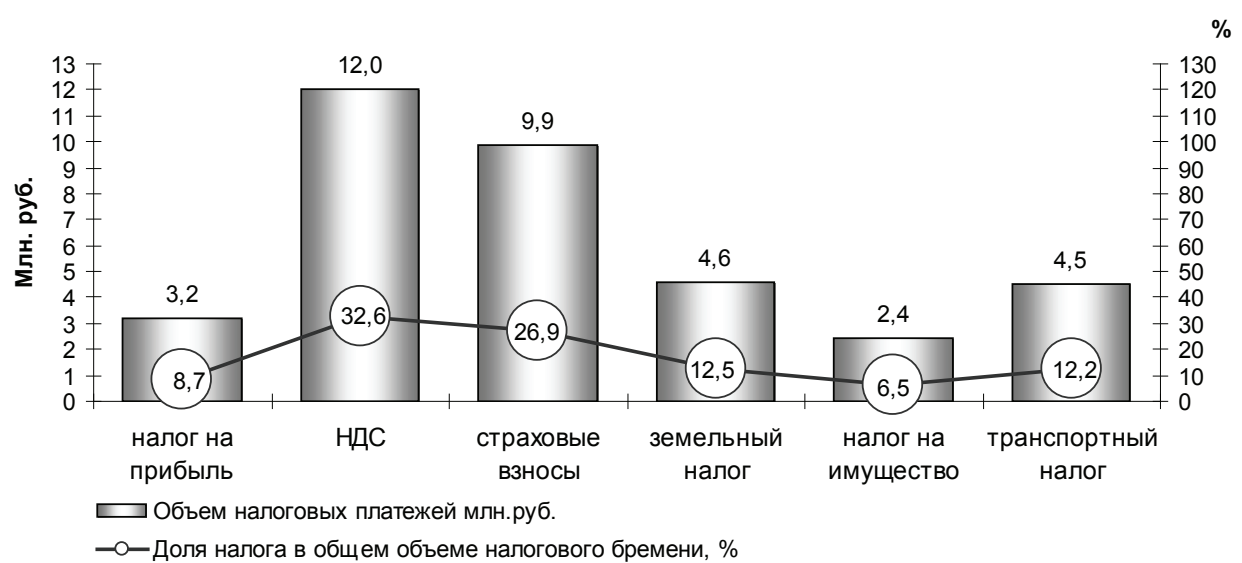

Рисунок 3. Величина налоговых платежей при использовании общего режима налогообложения 
Прогнозирование и планирование в налогообложении

\section{Таблица 5.}

Объем налоговых платежей при специальном режиме налогообложения (ЕСХН) по сельскохозяйственному производству исследуемого интегрированного объединения, тьс. руб.

\begin{tabular}{|c|c|c|c|}
\hline Налоговые платежи & $\mathbf{2 0 1 0}$ г. & $\mathbf{2 0 1 1}$ г. & $\mathbf{2 0 1 2}$ г. \\
\hline Всего налогов & 22343 & 24240 & 25424 \\
\hline ЕСХН & 8103 & 4730 & 4879 \\
\hline Транспортный налог & 4505 & 5095 & 5095 \\
\hline Земельный налог & 4632 & 5614 & 6007 \\
\hline
\end{tabular}

Объем налоговых платежей при специальном режиме

налогообложения (ЕСХН) в разрезе хозяйств), тьс. руб.

\begin{tabular}{|c|c|c|c|c|}
\hline & ECXH & $\begin{array}{c}\text { транспортный } \\
\text { налог }\end{array}$ & $\begin{array}{c}\text { земельный } \\
\text { налог }\end{array}$ & всносы в п/ф \\
\hline Предприятие 1 & 274 & 12 & 505 & 563 \\
\hline Предприятие 2 & 1570 & 4075 & 578 & 633 \\
\hline Предприятие 3 & 1362 & 152 & 793 & 875 \\
\hline Предприятие 4 & 1104 & 220 & 716 & 790 \\
\hline Предприятие 5 & 825 & 32 & 383 & 418 \\
\hline Предприятие 6 & 978 & 3 & 811 & 892 \\
\hline Предприятие 7 & 575 & 5 & 377 & 413 \\
\hline Предприятие 8 & 1414 & 6 & 469 & 520 \\
\hline Предприятие 9 & 914 & 5 & 381 & 502 \\
\hline Предприятие 10 & 1011 & 7 & 514 & 612 \\
\hline
\end{tabular}

зовании общего режима налогообложения составит 36,8 млн. руб.

Рассмотрим величину и структуру налогового бремени при применении специального режима налогообложения (ЕСХН) (табл. 5).

Величина налоговых платежей при данном режиме налогообложения в 2010 г. будет составлять 22,3 млн. руб., что в 2 раза меньше суммарной величины при общем режиме налогообложения.

Наибольший объем налоговых отчислений в государственный бюджет также как и при общем режиме налогообложения поступит от наиболее крупных и прибыльных хозяйств «Предприятие 3 » 3,1 млн. руб.) и «Предприятие $2 »(6,8$ млн. руб.) (приложение 17). При специальном режиме налогообложения наибольший удельный вес приходится на ЕСХН (8,1 млн. руб.) и земельный налог (4,6 млн. руб.). Суммарный объем данных налогов в общей величине налогового бремени составит более $70 \%$.

Календарь движения налоговых платежей по сельскохозяйственному производству 
DOI: $10.7256 / 1812-8688.2013 .10 .9729$

При цитировании этой статьи сноска на doi обязательна

\section{Налоги и налогообложение - №10(112)• 2013}

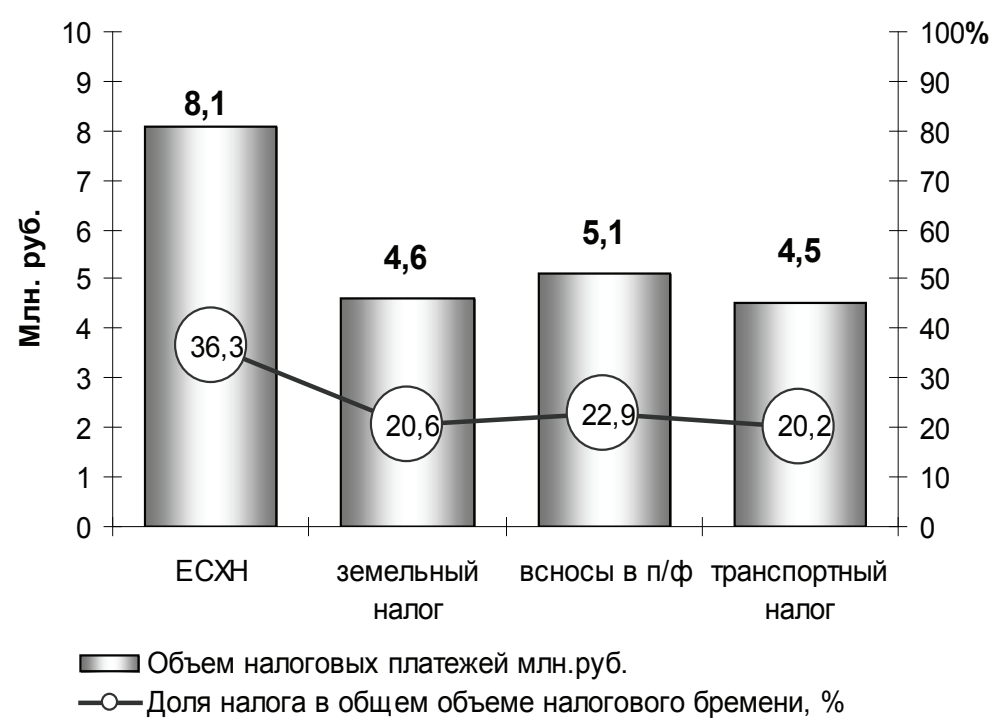

Рисунок 4. Величина налоговых платежей при использовании ЕСХН

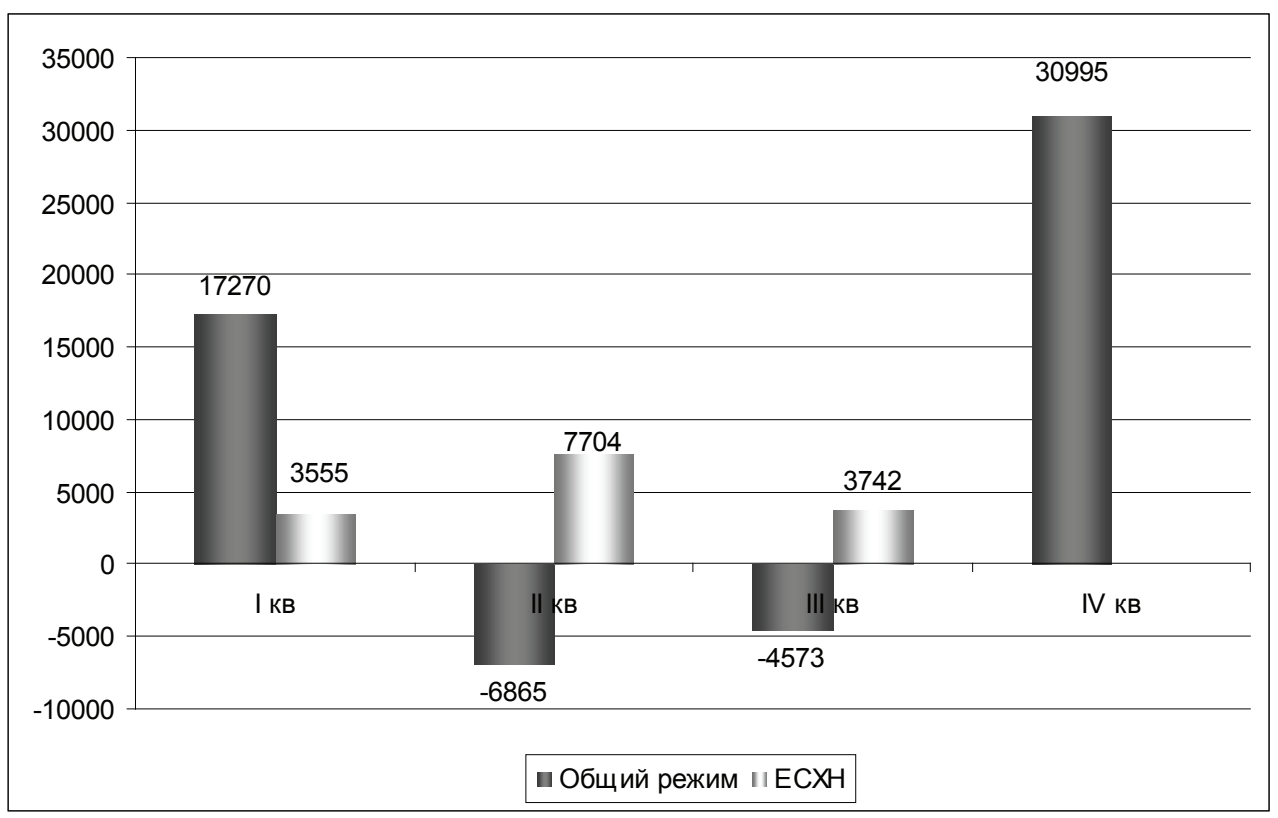

Рисунок 5. Величина налогов, уплачиваемая по квартально при различных режимах налогообложения

группы компаний при нахождении сельхозпредприятий на различных налоговых режимах будет выглядеть следующим образом (рис.5).

Так, при ЕСХН предприятиям наиболее тяжело обеспечить свои налоговые обязательства во втором и третьем кварталах, когда они не имеют свободных денежных средств в обороте, пользуются кредитны- ми ресурсами и несут затраты, связанные с проведением технологических операций. В данный период времени сельхозтоваропроизводители испытывают наибольшую потребность в финансовом обеспечении, поскольку около $70 \%$ затрат уже совершено, $30 \%$ еще предстоит совершить в 4 квартале, а до получения выручки от реализации продукции еще далеко. 
DOI: $10.7256 / 1812-8688.2013 .10 .9729$

При цитировании этой статьи сноска на doi обязательна

Прогнозирование и планирование в налогообложении

Таблица 7.

Величина налоговых платежей по холдингу при различных режимах налогообложения, тыс. руб.

\begin{tabular}{|c|c|c|c|}
\hline Показатель & $2010 \Gamma$ & 2011 г. & 2012 r \\
\hline Всего налогов в головной компании & 7520 & 8542 & 8951 \\
\hline $\begin{array}{c}\text { Всего налогов на общем режиме } \\
\text { (по сельскохозяйственным предприятиям) }\end{array}$ & 36827 & 29047 & 32762 \\
\hline $\begin{array}{c}\text { Всего налогов при ЕСХН } \\
\text { (по сельскохозяйственным предприятиям) }\end{array}$ & 22343 & 24240 & 25424 \\
\hline Потери от НДС головной компании & 29145 & 37850 & 41138 \\
\hline $\begin{array}{c}\text { Всего налогов головной компании } \\
\text { (если сельскохозяйственные } \\
\text { организации применяют ЕСХН) }\end{array}$ & 36665 & 46392 & 50089 \\
\hline Итого по холдингу при ЕСХН & 59008 & 70632 & 75513 \\
\hline Итого по холдингу при общем режиме & 44347 & 37589 & 41713 \\
\hline
\end{tabular}

Мы считаем, что для того, чтобы выбрать наиболее эффективную систему налогообложения в целом по интегрированному формированию, необходимо оценить потери головной компании от НДС, не принятого к возмещению при специальном налоговом режиме (ЕСХН), и сопоставить получившиеся результаты (табл. 7).

Так, потери головной компании от НДС, не принятого к возмещению при специальном налоговом режиме (ECXH), в 2010 г составят. 29,1 млн. руб., в (2011 г.- 37,8 млн. руб., 2012 г.- 41,1 млнруб.), а всего налогов головная компания уплатит в размере 7,5 млн. руб. Таким образом, всего по агрохолдингу при использовании специального налогового режима (ЕСХН) для сельскохозяйственных предприятий, входящих в его состав, будет уплачено налогов на сумму 59,0 млн. руб., а при использовании общего режима налогообложения для всех предприятий интегрированного формирования - 44,3 млн. руб., что на 24,9\% меньше. Это означает, что наиболее эффективной для исследуемого холдинга является налоговая схема с использованием общего режима налогообложения для всех предприятий, входящих в его состав.

Таким образом, нам представляется, что оптимизацию налогообложения в сельскохозяйственных предприятиях, в том числе и интегрированных, следует основывать на:

- четком соблюдении принципов налоговой оптимизации;

- выборе оптимальной организационноправовой формы хозяйствования предприятий;

- учете влияния субъективных и объективных факторов, а также отраслевых особенностей при выборе той или иной системы налогообложения;

- выборе методов учета доходов и расходов;

- использовании различных критериев оценки с целю обоснованного выбора оптимальной налоговой схемы 


\section{Библиография}

1. Пестрякова Т. П. Система налогового планирования сельскохозяй-ственного предприятия / Т. П. Пестрякова // Экономический анализ: теория и практика.— 2007.- № 5.- С. 25-30.

2. Брызгалин А. В. Налоговая оптимизация: принципы, методы, рекомендации, арбитражная практика / А. В. Брызгалин, В. Р. Берник, А. Н. Головкин; под ред. канд. юр. наук

А. В. Брызгалина. 4-е изд., перераб. и доп.- М.: Юрайт-Издат, 2007.- 320 c.

3. Кацыка А. В. Оптимизация налогообложения в рамках существую-щего законодательства / А. В. Кацыка // Консультант бухгалтера.- № 12.2007.- C. 48-58.

4. Лукаш Ю. А. Оптимизация налогов. Методы и схемы / Ю. А. Лукаш.- М.: ГроссМедиа, 2006.- 416 с.

5. Налоговый кодекс Российской Федерации: Части первая и вторая.М.: Юрайт-Издат, 2013.- 642 с.

6. Шиткина И. С. Особенности правового статуса холдинга и его уча-стников в налоговом законодательстве / И. С. Шиткина // Хозяйства и право.-
2005. - № 8.- C. 102-119.

7. Ермакова М. С. Особенности формирования учетной политики для целей налогообложения агрохолдинга // NB: Финансовое право и управление.2013.- 2.- C. 77-105. URL: http:// www.e-notabene.ru/flc/article_778.html

8. Чхутиашвили Л. В. Перспективы развития системы налогообложения малого предпринимательства в условиях рынка // NB: Финансовое право и управление.- 2013.-1.- C. 64-99. URL: http://www.e-notabene.ru/flc/article_528. html

9. Агузарова Ф. С. Некоторые вопросы модернизации налоговой системы Российской Федерации // NB: Финансовое право и управление.2013.-2.- C. 24-44. URL: http:// www.e-notabene.ru/flc/article_629.html

10. Казьмин А.Г., Оробинская И. В. Анализ поступления налогов в бюджеты областей Центрально-Чернозёмного района // NB: Финансовое право и управление.- 2012.- 1.- С. 156-211. DOI: 10.7256/2306-4234.2012.1.358. URL: http://www.e-notabene.ru/flc/article_358. html

\section{References (transliterated)}

1. Pestryakova T. P. Sistema nalogovogo planirovaniya sel'skokhozyai-stvennogo predpriyatiya / T. P. Pestryakova // Ekonomicheskii analiz: teoriya i praktika.-2007.- № 5.- S. 25-30.

2. Bryzgalin A. V. Nalogovaya optimizatsiya: printsipy, metody, reko-mendatsii, arbitrazhnaya praktika / A. V. Bryzgalin, V. R. Bernik, A. N. Go-lovkin; pod red. kand. yur. nauk A. V. Bryzgalina. 4-e izd., pererab. i dop.- M.: Yurait-Izdat, 2007.$320 \mathrm{~s}$.

3. Katsyka A. V. Optimizatsiya nalogooblozheniya $\mathrm{v}$ ramkakh sushchestvuyu-shchego zakonodatel'stva / A. V. Katsyka // Konsul'tant bukhgaltera.- № 12.— 2007.- S. 48-58.

4. Lukash Yu.A. Optimizatsiya nalogov. Metody i skhemy / Yu.A. Lukash.- M.: GrossMedia, 2006.-416 c. 
5. Nalogovyi kodeks Rossiiskoi Federatsii: Chasti pervaya i vtoraya.- M.: YuraitIzdat, 2013.- $642 \mathrm{~s}$.

6. Shitkina I. S. Osobennosti pravovogo statusa kholdinga i ego ucha-stnikov v nalogovom zakonodatel'stve / I. S. Shitkina // Khozyaistva i pravo. - 2005.— № 8.- S. 102-119.

7. Ermakova M. S. Osobennosti formirovaniya uchetnoi politiki dlya tselei nalogooblozheniya agrokholdinga // NB: Finansovoe pravo i upravlenie. - 2013.2.- C. 77-105. URL: http://www.enotabene.ru/flc/article 778.html

8. Chkhutiashvili L. V. Perspektivy razvitiya sistemy nalogooblozheniya malogo predprinimatel'stva v usloviyakh rynka
// NB: Finansovoe pravo i upravlenie.2013.-1.- C. 64-99. URL: http:// www.e-notabene.ru/flc/article_528.html

9. Aguzarova F. S. Nekotorye voprosy modernizatsii nalogovoi sistemy Rossiiskoi Federatsii // NB: Finansovoe pravo i upravlenie.- 2013.- 2.-C. 24-44. URL: http://www.e-notabene.ru/ flc/article_629.html

10. Kaz'min A.G., Orobinskaya I. V. Analiz postupleniya nalogov v byudzhety oblastei Tsentral'no-Chernozemnogo raiona // NB: Finansovoe pravo i upravlenie.-2012.1.- C. 156-211. DOI: $10.7256 / 2306-$ 4234.2012.1.358. URL: http://www.enotabene.ru/flc/article_358.html 